\title{
Multiple Loci Condition Seed Transmission of Soybean mosaic virus (SMV) and SMV-Induced Seed Coat Mottling in Soybean
}

\author{
Leslie L. Domier, Houston A. Hobbs, Nancy K. McCoppin, Charles R. Bowen, \\ Todd A. Steinlage, Sungyul Chang, Yi Wang, and Glen L. Hartman
}

First, third, fourth, and eighth authors: United States Department of Agriculture-Agricultural Research Service and Department of Crop Sciences, University of Illinois, Urbana 61801; and second, fifth, sixth, and seventh authors: Department of Crop Sciences, University of Illinois, Urbana.

Accepted for publication 19 January 2011.

\begin{abstract}
Domier, L. L., Hobbs, H. A., McCoppin, N. K., Bowen, C. R., Steinlage, T. A., Chang, S., Wang, Y., and Hartman, G. L. 2011. Multiple loci condition seed transmission of Soybean mosaic virus (SMV) and SMVinduced seed coat mottling in soybean. Phytopathology 101:750-756.

Infection of soybean plants with Soybean mosaic virus (SMV), which is transmitted by aphids and through seed, can cause significant reductions in seed production and quality. Because seedborne infections are the primary sources of inoculum for SMV infections in North America, hostplant resistance to seed transmission can limit the pool of plants that can serve as sources of inoculum. To examine the inheritance of SMV seed

Consequently, a recombinant inbred line population was derived from a cross between PIs 88799 and 548391 and evaluated for segregation of SMV seed transmission, seed coat mottling, and simple sequence repeat markers. Chromosomal regions on linkage groups $\mathrm{C} 1$ and $\mathrm{C} 2$ were significantly associated with both transmission of isolate SMV 413 through seed and SMV-induced seed coat mottling, and explained $\approx 42.8$ and $46.4 \%$ of the variability in these two traits, respectively. Chromosomal regions associated with seed transmission and seed coat mottling contained homologues of Arabidopsis genes DCL3 and RDR6, which encode enzymes involved in RNA-mediated transcriptional and posttranscriptional gene silencing.
\end{abstract} transmission in soybean, crosses were made between plant introductions (PIs) with high (PI88799), moderate (PI60279), and low (PI548391) rates of transmission of SMV through seed. In four $\mathrm{F}_{2}$ populations, SMV seed transmission segregated as if conditioned by two or more genes.
Additional keywords: quantitative trait loci, RNA silencing, virus movement.
Soybean mosaic virus (SMV), a member of the family Potyviridae of plant viruses, can cause significant yield losses and reductions in seed quality in soybean (Glycine $\max$ (L.) Merr.) $(29,31)$. In addition to being transmitted by multiple species of aphids, SMV, like $\approx 15 \%$ of plant virus species, is transmitted through seed at rates of 0 to $>40 \%$ depending on the virus isolate and soybean genotype $(7,21,32)$. In North America, SMV rarely infects alternative host species, and seedborne infections are the primary sources of inoculum for SMV infections (29). In soybean, at least three loci (Rsvl, Rsv3, and Rsv4) condition resistance to infection by SMV $(9,41,48)$. Resistance to SMV in plants expressing alleles of Rsvl or Rsv3 is strain specific, and some combinations of resistance gene alleles and SMV isolates show necrotic hypersensitive responses in infected plants $(9,13,24)$. The Rsv4 locus produces seedling resistance to most SMV isolates but systemic symptoms can appear as plants mature (27). Combinations of SMV resistance loci yield complete resistance to most SMV isolates $(50,62)$. Because some soybean genotypes showed high levels of resistance to seed transmission of all SMV isolates tested $(7,21)$, resistance to transmission of SMV through seed may provide a strategy to limit the pool of plants that can serve as sources of inoculum and, thereby, reduce the incidence of disease.

In most plant-virus systems analyzed, seed transmission is dependent upon both host and virus genotypes (37). Host genetics

Corresponding author: L. L. Domier; E-mail address: leslie.domier@ars.usda.gov

doi:10.1094/PHYTO-09-10-0239

This article is in the public domain and not copyrightable. It may be freely reprinted with customary crediting of the source. The American Phytopathological Society, 2011 of seed transmission has been examined in at least three systems. In an $\mathrm{F}_{2}$ population of a cross between susceptible and resistant barley (Hordeum vulgare (L.)) lines to seed transmission of Barley stripe mosaic virus (BSMV), resistance to seed transmission segregated as a single recessive gene (11). In contrast, Wang and Maule (70) observed a near-continuous distribution of seed transmission rates for Pea seed-borne mosaic virus (PSbMV) in $\mathrm{F}_{2}$ populations of crosses between two pea (Pisum sativum (L.)) cultivars. Similarly, resistance to seed transmission of Alfalfa mosaic virus (AMV) was controlled by multiple genes in a quantitative manner in an $\mathrm{F}_{2}$ population derived from two Medicago murex (L.) accessions (54).

In plants infected with PSbMV, a Potyvirus sp. related to SMV, seed transmission results from direct invasion of developing embryos through a transient symplastic pathway that connects the base of the suspensor to the developing embryo (59). Multiple studies have suggested that RNA silencing and trafficking are involved in limiting virus movement through the suspensor and into embryos. For example, coat protein and helper component/ protease (HC-Pro) are determinants for seed transmission of PSbMV (38). HC-Pro is a multifunctional protein that facilitates aphid and seed transmission and long-distance movement and is a potent suppressor of RNA silencing $(3,18)$. RNA silencing is a sequence-specific process of regulating the abundance of RNA transcripts in eukaryotic cells that also serves as an adaptive antiviral defense in plants (19). During virus infections, RNA silencing is activated by double-stranded RNA (dsRNA) (5). Sequence specificity of RNA silencing is imparted by multiple classes of short (21 to 24 nucleotides) interfering RNAs (siRNAs) produced from virus dsRNA by RNase III-type enzymes called dicer-like (DCL) proteins in plants (5). One strand of each siRNA 
is combined with argonaute (AGO) proteins into RNA-induced silencing complexes (RISCs) and direct degradation of complementary viral RNA sequences (5). In addition, host RNA-dependent RNA polymerase 6 (RDR6) is required for production of secondary siRNAs, which are the primary effectors of RNAmediated antiviral defenses in plants (71).

The lack of seed pigmentation in most cultivated soybeans is conditioned by alleles at the $I$ locus, which suppress the accumulation of chalcone synthase (CHS) mRNAs in seed coats by RNA silencing $(61,67)$. Different alleles of the $I$ locus contain inverted repeats of the entire CHS gene cluster, convergently transcribed CHS genes, or inverted repeats of individual CHS genes that produce dsRNAs that lead to the production of siRNAs and RNAmediated tissue-specific silencing of CHS genes and loss of pigmentation $(16,39,68)$. SMV infections often induce mottling of soybean seed coats in a host and virus strain-specific manner. The mottling of soybean seed coats in plants infected with SMV results from partial suppression of RNA silencing of the CHS mRNAs by SMV HC-Pro (61). In a related phenomenon, soybean plants that are exposed to low temperatures $\left(\approx 15^{\circ} \mathrm{C}\right)$ during flowering show similar patterns of seed coat mottling that also are dependent upon the $I$ locus that results from inhibition of RNA silencing at low temperatures (39).

Strain-line interactions in seed transmission and seed coat mottling suggest that there are very specific interactions of virus and host components in movement of SMV into soybean embryos and suppression of silencing. To examine the genetics of resistance to seed transmission of SMV in soybean and establish systems to study the interactions between host and virus factors in seed transmission, the inheritance of SMV seed transmission was investigated. Candidate gene analysis showed that genes associated with RNA silencing were located within the chromosomal regions significantly associated with SMV seed transmission and seed coat mottling.

\section{MATERIALS AND METHODS}

Virus strains and plant materials. Three field isolates of SMV (413, 746, and 88799), which are transmitted through seed at rates $\leq 40 \%$ depending on the soybean cultivar, and three soybean plant introductions (PIs) with high (PI88799), moderate (PI60279), and low (PI548391) incidence of SMV seed transmission were used in these studies (21). For studies with $\mathrm{F}_{2}$ populations, SMV isolates were maintained by seed transmission in PI229358. For analysis of seed transmission in the recombinant inbred line (RIL) population, a full-length infectious clone of SMV 413 was constructed. Briefly, SMV 413 virions were purified (25) and virus RNA was extracted; reverse transcribed with SuperScript II (Invitrogen, Carlsbad, CA) and an oligo(dT) primer (5'-gagagagaggtcgacttttttttttttttttt-3'); amplified using iProof high-fidelity DNA polymerase (Bio-Rad, Hercules, CA), the oligo(dT) primer, and 5'-gtgtggtacctaatacgactcactatagaaattaaaactactcataaagacaac-3' (T7 RNA polymerase promoter underlined); and cloned into pCR TOPO4 (Invitrogen). The sequence of the infectious clone was determined (GenBank accession number GU015011). Inoculum for the RIL population was prepared from systemically infected leaves of soybean seedlings inoculated with capped in vitro transcripts synthesized with the mMESSAGE mMACHINE Kit (Ambion, Austin, TX) (20).

Segregation of SMV seed transmission. Segregation of SMV seed transmission was assayed in four $F_{2}$ populations derived from one cross between PI60279 and PI88799 (41 plants) and three crosses between PI548391and PI88799 (43, 56, and 96 plants). $F_{2}$ seedlings from PI60279×PI88799 and PI548391× PI88799 were inoculated with SMV 746 and grown to maturity in the field; $F_{2}$ seedlings from crosses of PI548391×PI88799 were inoculated with SMV 413 or SMV 88799 and grown to maturity in the greenhouse. A population of $148 \mathrm{~F}_{6}$ RILs was planted in the field in a randomized complete block design with four replications and inoculated with SMV 413 (inoculum prepared from plants inoculated with infectious in vitro transcripts) at growth stage V2. SMV infections were confirmed either by tissue-blot immunoassay (46) or double-antibody sandwich enzyme-linked immunosorbent assay (Agdia, Elkhart, IN). Plants that were negative in immunoassays were reinoculated with SMV and reassayed for virus infection. For all crosses, seed transmission rates were determined by planting $\leq 108$ seeds from each SMVinfected plant in 72-well polystyrene trays containing soilless mix (Sunshine Mix LC1; Sun Gro Horticulture Inc., Bellevue, WA). SMV infections were detected by tissue-blot assay or visual inspection of seedlings beginning at 10 days after planting. For the RIL population, seed were visually evaluated for percent nonmottled seed and the color of seed coat mottling (black or brown).

Marker analysis. For analysis of RILs, DNA was extracted from leaves pooled from $12 \mathrm{~F}_{7}$ seedlings using Qiagen (Valencia, CA) Plant mini DNA kits. DNA was extracted from parental lines and evaluated with 492 simple sequence repeat (SSR) primer pairs. DNA from 148 RILs from crosses between PI88799 and PI548391 were analyzed with 116 polymorphic SSR markers as described by Wang et al. (69). In regions proximal to loci significantly associated with SMV seed transmission where none of the previously reported SSR markers were polymorphic, additional primer pairs (Gm04_067, 5'-tggattttactggecttcca-3' and 5'aatgctgaaaatgcctgagc-3'; Gm04_119, 5'-tccttcgaggcacaatcttt-3' and 5'-ggcettcgataaaatgcaaa-3'; Gm04_476 Gm04_507, 5'-tggagcctttgatagcatga-3' and 5'-tgatgaatttgtccaggtttt-3'; Gm04_5807, 5'atgaggtggtgatgatacatgc- $3^{\prime}$ and $5^{\prime}$-tcatactgtgtcgtttgtgtcg- $3^{\prime}$; Gm04_6579, 5'-cgggccacaataacaaaatc-3' and 5'-atgtagtaatgcggcgtcct-3'; Gm06_134, 5'-tcccaaatggtccttaaagtaaga-3' and 5'-ccetgagttggtatatttcacc-3'; Gm06_427 5'-attggtccetacacatctccac-3' and $5^{\prime}$-gcaatccttaatcatccaccat-3'; Gm06_573 5'-gcttcccacgactcaaaaac-3' and 5'-tgggcattgtcagcttgtta-3'; and Gm06_598 5'-tatgaacaaaaggcgcacac- $3^{\prime}$ and $5^{\prime}$-tcacgattagaccgacctaa- $3^{\prime}$ ) flanking SSRs in the soybean genome (60) were selected using WebSat (51). Relative positions of markers were confirmed using MapMaker/EXP 3.0b (43). Quantitative trait loci (QTL) were identified by inclusive composite interval mapping (44) as implemented in QGene 4.0 (36). Genome-wide significance log likelihood ratio (LOD) thresholds at an $\alpha=0.05$ confidence level were determined for each trait using 1,000 iterations of permutation analysis (15). Epistatic interactions between loci were evaluated using QTL Network 2.1 (72) at a significance level of $P=0.05$.

Candidate gene analysis. Amino acid sequences of Arabidopsis thaliana genes reported to be involved in transcriptional and posttranscriptional gene silencing (AtAGO1 [NP_849784], AtAGO5 [NP_850110], AtAGO7 [NP_177103], AtAGO10 [NP_199194], AtAS2 [NP_001117553], AtCLSY1 [NP_189853], AtDCL1 [NP_171612], AtDCL2 [NP_566199], AtDCL3 [ABF19799], AtDCL4 [NP_197532], AtDRB2 [NP_565672], AtDRB3 [NP_001030779], AtDRB4 [NP_974480], AtDRB5 [NP_565672], >AtDRD1 [NP_179232], AtDRH1 [NP_001030619], AtDRM2 [NP_196966] AtHAT [NP_187155], AtHEN1 [NP_567616], AtHEN2 [NP_565338], AtHYL1 [NP_563850], AtNRPD1a [NP_176490], AtSDE5 [NP_188158], AtSGS3 [NP_197747], AtRDR1 [NP_172932], AtRDR2 [NP_192851], AtRDR6 [NP_190519], AtSDE3 [NP_172037], and AtSERRAT [NP_565635]], $(6,28,52,55,58)$; soybean seed color (GmCHS1 [ABB30178], GmCHS9 [ABQ63059], and GmT [AAO47844]); HC-Pro-interacting proteins from Nicotiana benthamiana, N. tabacum, Solanum tuberosum, and Zea mays (NbrgsCAM [AAK11255] [2]; StHIP1 [CAD45374] and StHIP2 [CAD45375] [23]; ZmFDX5 [NP_001105344] [14], NtMinD [ABU96467] [35]; and AtPAA2 [AAC32055], AtPBB2 [AAC32067], and AtPBE1 [AAC32072] [34]); and embryospecific transport genes (AtISE1 [NP_172737] and AtISE2 
[NP_177164]) (63) were compared with the longest amino acid sequences derived from high-confidence $G$. max gene models using BLASTP $(1,60)$ in Seqtools 8.4 (www.seqtools.dk). The positions of the genes on the linkage map were extrapolated from the position in the soybean genome of the nearest flanking SSR markers. Class designations of soybean candidate genes were

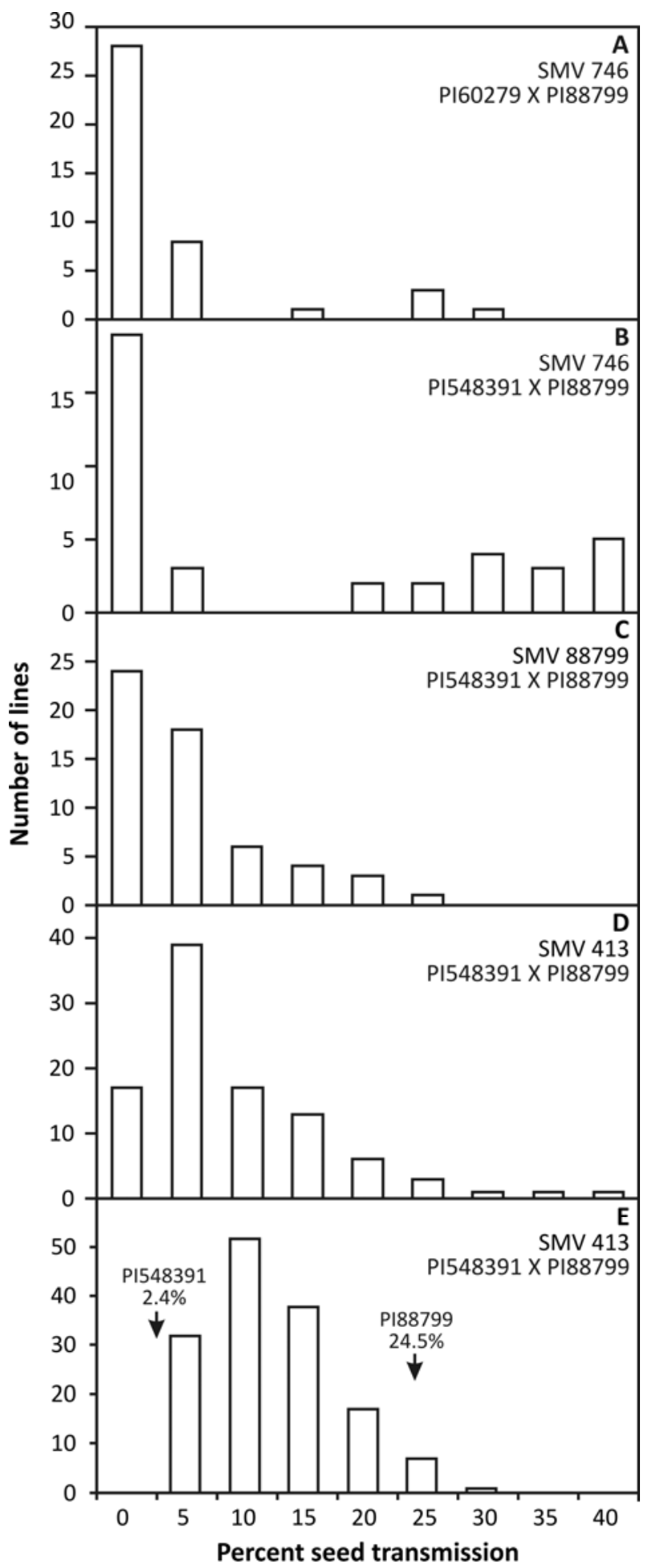

Fig. 1. Segregation of Soybean mosaic virus (SMV) seed transmission in soybean populations. Segregation of SMV seed transmission was assayed in $\mathbf{A}$ to $\mathbf{D}$, four $\mathrm{F}_{2}$ populations and $\mathbf{E}$, an $\mathrm{F}_{3: 6}$ population derived from crosses between A, plant introductions (PIs) 88799 and 60279 and $\mathbf{B}$ to E, PIs 88799 and 548391. Seedlings were inoculated with SMV isolates 746 (A and B), 88799 (C), and 413 (D and E) and grown to maturity in the field (A, B, and E) or greenhouse (C and D). Seed were harvested, planted, and tested for SMV infection by tissue-blot immunoassay. inferred by nearest neighbor analysis of multiple alignments of predicted amino acid sequences of Arabidopsis, G. max, and N. benthamiana sequences using ClustalX (65) and MEGA4 (64).

To determine nucleotide sequences of the coding regions of Glyma04g06060, Glyma04g07150, and Glyma06g07250 from PI548391 and PI88799, total RNA was extracted from trifoliolate leaves of PI548391 and PI88799 using a Qiagen RNeasy Plant Mini Kit, reverse transcribed with SuperScript II, and amplified using iProof high-fidelity DNA polymerase and $5^{\prime}$-tatct gtgggtcatcttgctat- $3^{\prime}$ and $5^{\prime}$-gagagagctctaactagaagggagaggatcaatttc$3^{\prime}$ for Glyma04g06060 and 5'-gagaggtaccatggacttagaag gaagtgaaaaggg- $3^{\prime}$ and $5^{\prime}$-gagagagctcttataacctttcagatagatactttgc- $3^{\prime}$ for Glyma04g07150 and Glyma06g07250. Because amplifications of Glyma04g06060 produced single bands, polymerase chain reaction (PCR) products were sequenced directly. For Glyma04g07150 and Glyma06g07250, PCR products were cloned into pCR TOPO4 and at least two clones were sequenced from each soybean line for each gene. Sequences were assembled and single-nucleotide polymorphisms (SNPs) were identified using Sequencher 4.10.1 (Gene Codes, Ann Arbor, MI).

\section{RESULTS}

Segregation of transmission of SMV through seed in $\mathbf{F}_{2}$ populations. As previously reported $(7,21)$, virus isolate $\times$ line interactions were observed in SMV seed transmission in preliminary studies with four $\mathrm{F}_{2}$ populations (Fig. 1). In all $\mathrm{F}_{2}$ populations, most plants showed no or very low SMV seed transmission. Multiple soybean genes appeared to be required for susceptibility (i.e., high rates) to SMV seed transmission. The progeny of $\mathrm{F}_{2}$ plants derived from crosses between PI60279 and PI88799 and between PI548391and PI88799 that were inoculated with SMV isolates 413 and 88799 showed near-continuous variation for seed transmission of SMV (Fig. 1C to E). In contrast, the progeny of $F_{2}$ plants from the cross between PI548391 and PI88799 that were inoculated with SMV isolate 746 showed discontinuous variation in seed transmission of SMV (Fig. 1A and B). Because of the quantitative nature of the trait, $F_{3}$ plants from crosses between PI548391 and PI88799 were advanced by singleseed descent to generate a population of RILs for further analyses (see below).

Segregation of color of seed coat mottling in RILs. To verify the mapping techniques used in this study, seed coat color, which is conditioned by the $R$ locus (66), was evaluated along with SSR markers in the RIL population. Color of seed coat mottling (black versus brown) segregated in a 3:1 ratio (91 black to 42 brown; $\left.\chi^{2}=0.080, P=0.78\right)$ in the RIL population and mapped proximal to Sat_293 on linkage group (LG) K, which is $\approx 2$ centimorgans from the $R$ locus. These results confirm the segregation and mapping of this classic genetic locus in the RIL population.

QTL analysis of SMV seed transmission and SMV-induced seed coat mottling. Parental lines PI548391 and PI88799 were evaluated for polymorphisms with 421 previously mapped microsatellite markers (17) and 71 markers designed from the soybean genome sequence. From these, 116 were polymorphic and were scored in the RIL population. Permutation analysis identified a LOD significance threshold of 2.9 at an $\alpha=0.05$ confidence level for SMV seed transmission. In all four replications of the analysis of the RILs, two chromosome regions proximal to Sat_337 (LOD 11.7) on LG C1 (chromosome 4) and Satt227 (LOD 4.2) on LG C2 (chromosome 6) showed significant associations with seed transmission of SMV. The LOD values were highest with the data averaged over the four replications (Fig. 2). The two loci explained $42.8 \%$ of the variability in seed transmission of SMV. An interval on LG F proximal to Satt522 was associated with transmission of SMV through seed but, at a LOD of 2.5, it was below the significance threshold (data not shown). The percentage of nonmottled seed was associated with the same loci on LGs C1 
(LOD 6.8) and C2 (LOD 10.0) (Fig. 2). The two loci explained $46.4 \%$ of the variability in SMV-induced seed coat mottling. Significant epistatic interactions were not detected between loci for either trait. Additional loci with LOD values of 2.4 and 2.8, both below the threshold value, were detected on LGs H (proximal to Satt192) and O (proximal to Sat_274), respectively (data not shown). Because of the lack of polymorphic previously described SSR markers proximal to initially significant loci, 10 new SSR markers (Gm04_067, Gm04_119, Gm04_476, Gm04_507, Gm04_5807, Gm04_6579, Gm06_134, Gm06_427, Gm06_573, and Gm06_598) were identified from the soybean genome sequence and used to narrow the intervals (Fig. 2). The interval on LG A2 containing the $I$ locus had maximum LOD scores of 0.8 for seed transmission and 1.5 for percent mottled seed, indicating that, in this cross, the $I$ locus did not significantly affect either trait.

Candidate gene analysis. Seed transmission and seed coat mottling mapped to similar locations in the soybean genome and both phenomena have been linked to RNA silencing but did not map proximal to SMV resistance genes $R s v 1$, Rsv3, or $R s v 4$, which are located on LGs F, B2, and D1b, respectively (27, 33,74). A soybean homologue of Arabidopsis DCL genes was positioned within the significant interval on LG $\mathrm{C} 1$ (Glyma04g06060) and homologues of Arabidopsis and N. benthamiana RNA-dependent RNA polymerases were positioned within the significant intervals on LG C1 (Glyma04g07150) and LG C2 (Glyma06g07250) (Fig. 2). Consistent with G. max being a paleopolypoid (56), the soybean genome contained seven $D C L$ genes, two each related to $D C L 1, D C L 2$, and $D C L 4$, but only one complete homologue of DCL3 located between markers Sat_337 and Gm04_476 on LG C1. A second unannotated partial DCL3 homologue was located on chromosome 6 between positions 4,325,041 and 4,330,228, between markers Gm06_427 and Gm06_573 (Fig. 3). The soybean genome contained seven RNAdependent polymerase genes. Phylogenetic analysis showed that the two genes on LGs $\mathrm{C} 1$ and $\mathrm{C} 2$ were most closely related to AtRDR6 and NbRDR6.
Nucleotide sequences of the predicted coding regions of Glyma04g06060, Glyma04g07150, and Glyma06g07250 were determined from PI548391 and PI88799 from cDNAs amplified from total RNA. SNPs were detected between the two soybean lines in each of the cDNAs that would produce amino acid sequence differences in the corresponding proteins (Table 1). Nucleotide sequences of the predicted Glyma04g06060 coding regions from PI548391 and PI88799 differed at one position in each of the two regions that encode RNAse III domains of the DCL3 protein. The SNP at position 3,190 of the Glyma04g06060 coding region resulted in a Cys to Arg amino acid difference between the two soybean lines in the first RNAse III domain. The predicted coding sequences of Glyma04g07150 and Glyma06g07250 each differed at three positions between PI548391 and PI88799, which resulted in two and one amino acid sequence differences in the encoded proteins, respectively. At all nucleotide positions where the sequences of PI548391 and PI88799 differed in the three coding regions, the sequence of PI548391 was the same as that of the soybean genomic sequence, which was generated from 'Williams 82'. Like PI548391, Williams 82 shows very low levels of transmission of SMV through seed (data not shown). These data support the hypothesis that Glyma04g06060, Glyma04g07150, and Glyma06g07250 are involved in seed transmission of SMV.

\section{DISCUSSION}

In this study, we showed that transmission of three SMV isolates through seed was inherited as a polygenic trait, which is similar to results obtained for PSbMV in pea and AMV in Medicago spp. $(54,70)$. We identified two chromosomal regions significantly associated with SMV seed transmission and SMVinduced seed coat mottling on soybean LGs C1 (chromosome 4) and $\mathrm{C} 2$ (chromosome 6) that contained soybean homologues of Arabidopsis genes DCL3 and RDR6, both of which are involved in RNA silencing. Finally, we identified SNPs between soybean lines with low and high rates of transmission of SMV through seed

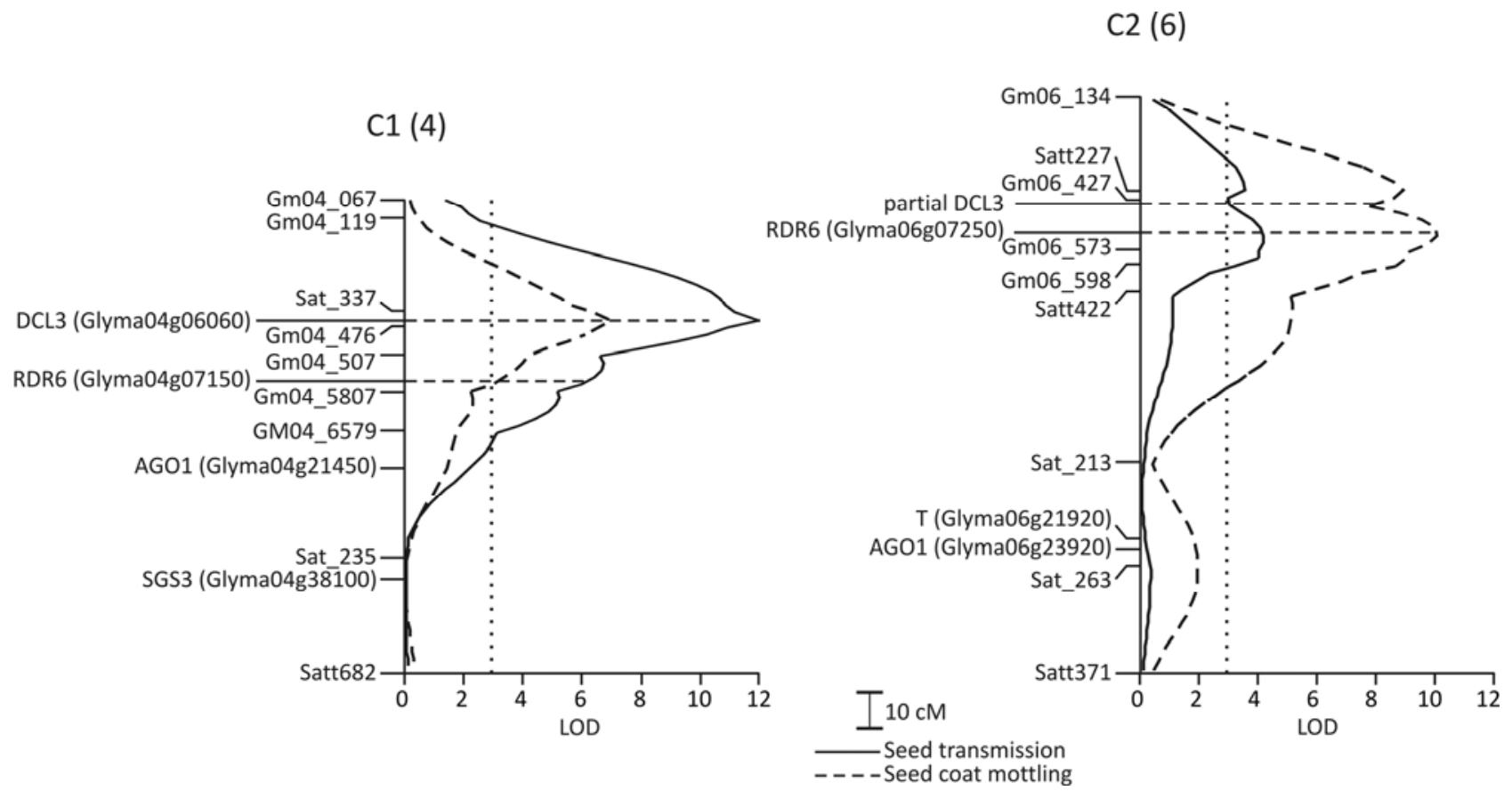

Fig. 2. Quantitative trait loci (QTL) associated with percent transmission of Soybean mosaic virus isolate 413 through seed and percent nonmottled seed on soybean linkage groups C1 (chromosome 4) and C2 (chromosome 6). Simple-sequence repeat markers were mapped in the recombinant inbred line population and QTL were identified using the mean percent seed transmission (solid line) and percent nonmottled seed (dashed line) by inclusive composite interval mapping. Permutation analysis identified genome-wide log-likelihood ratio significance thresholds of 2.9 at an $\alpha=0.05$ confidence level (dotted line). Positions of soybean genes predicted to encode proteins homologous to Arabidopsis proteins involved in RNA silencing are indicated on each map. 

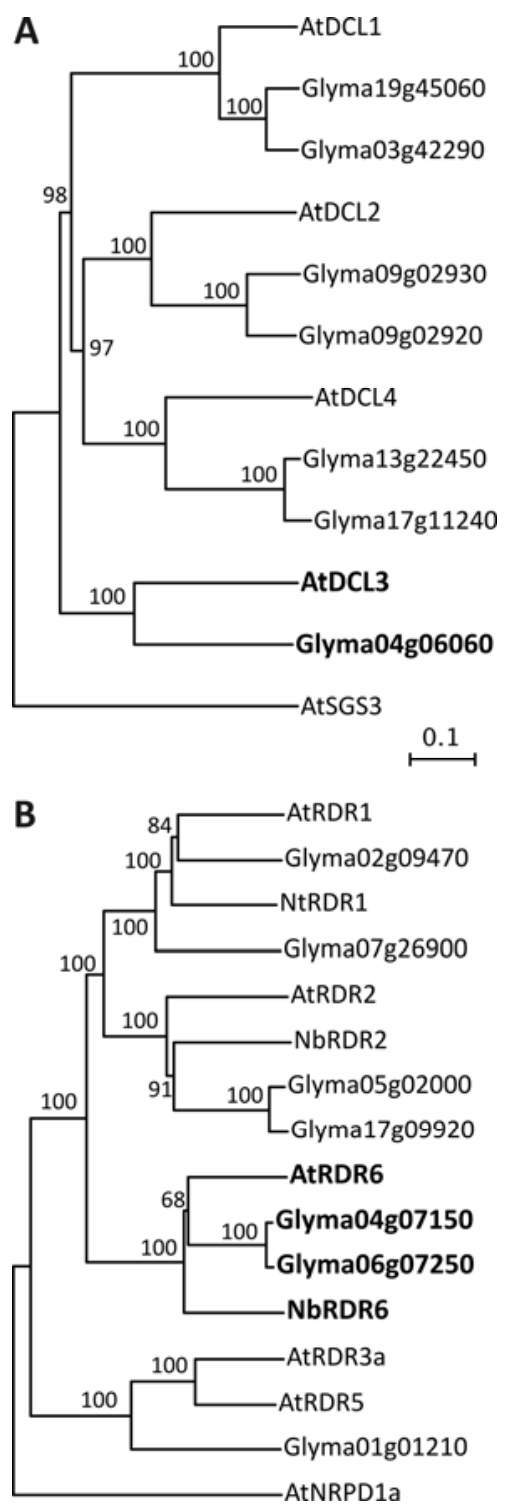

Fig. 3. Phylogenetic analysis of soybean candidate genes associated with loci for Soybean mosaic virus seed transmission and seed-coat mottling. Predicted amino acid sequences of $\mathbf{A}$, dicer-like (DCL) proteins and $\mathbf{B}$, RNA-dependent RNA (RDR) polymerases from Arabidopsis thaliana (At), Glycine max (Gm), and Nicotiana benthamiana $(\mathrm{Nb})$ were aligned using ClustalX and neighborjoining phylograms constructed using MEGA4. Class designations of soybean candidate genes were inferred by nearest-neighbor analysis of multiple alignments of predicted amino acid sequences. Amino acid sequences for A, AtSGS3 and B, AtNRPD1a were used as outgroups. Significant bootstrap values are indicated as percentage of 1,000 iterations that supported that node. in the predicted coding regions of the DCL3 (Glyma04g06060) and RDR6 (Glyma04g07150 and Glyma06g07250) homologues that would lead to amino acid sequence differences in the encoded proteins. BLAST searches of expressed sequence tag databases found multiple hits for homologues of DCL3 (Glyma04g06060) and RDR6 (Glyma04g07150 and Glyma06g07250) in short-read cDNA libraries prepared from globular embryos and suspensor cells of soybean and Scarlet Runner bean (Phaseolus coccineus (L.)) (e.g., GenBank accession nos. GD479958, GD903060, GD915397, GE040483, and GD688502). These findings are consistent with reports that have demonstrated associations between RNA silencing and movement of virus into embryos at very early developmental stages. DCL and RDR proteins also function in antiviral defenses, as is illustrated by the observations that mutations in DCL and RDR genes confer sensitivity to Cabbage leaf curl virus, Cucumber mosaic virus, Tobacco mosaic virus (TMV), and Turnip crinkle virus $(10,53,57,71)$.

The two intervals containing the QTL for seed transmission and seed coat mottling are very broad and contain many other genes. For example, the intervals on $\mathrm{C} 1$ and $\mathrm{C} 2$ both contain genes (Glyma04g05580 and Glyma06g05580) that are predicted to encode ATP-dependent DEAD-Box RNA helicases. DEAD-Box RNA helicases have been shown to be involved in embryo-specific cellto-cell transport (63). The two intervals also contain homologues (Glyma04g05210, Glyma04g06810, and Glyma06g06890) of the Z. mays KNOTTEDl gene. KNOTTED1-like proteins are involved in formation and maintenance of shoot apical meristems, increase size-exclusion limits of plasmodesmata, transport RNA to distal cells, and facilitate cell-to-cell movement of TMV in tobacco $(26,73)$. In addition, QTL for days to maturity (45), internode length (47), and cleistogamy (40) mapped proximal to one of the two intervals.

The propagation of RNA silencing through plants involves short- and long-distance movement of diffusible silencing signals, which recently were shown to be siRNA duplexes (22). For shortdistance movement, siRNA duplexes move 10 to 15 cells from the point of initiation through plasmodesmata. For long-distance movement, siRNA duplexes move through the vascular system. In Arabidopsis, DCL3 and RDR6 are involved in perception of the systemic silencing signals (8). DCL3 produces an RNase-III-type endonuclease that cleaves dsRNA into 24-nucleotide (nt) siRNAs that mediate RNA-directed DNA methylation and transcriptional silencing (12). RDR6 is required for production of secondary siRNAs (30). The finding that HC-Pro prevents plants from perceiving the systemic silencing signal but does not inhibit production of the signal (49) suggests that HC-Pro interferes with processes that involve the activities of DCL3 or RdR6, which is consistent with the results reported here.

SMV isolate-soybean line interactions in seed transmission phenotypes suggest that specific interactions between virus and host factors are required for efficient transmission of SMV through seed, which may explain the recessive nature of the trait.

TABLE 1. Single-nucleotide polymorphisms (SNPs) between plant introduction (PI)548391 and PI88799 in predicted coding regions of candidate genes located within chromosomal regions associated with seed transmission of Soybean mosaic virus

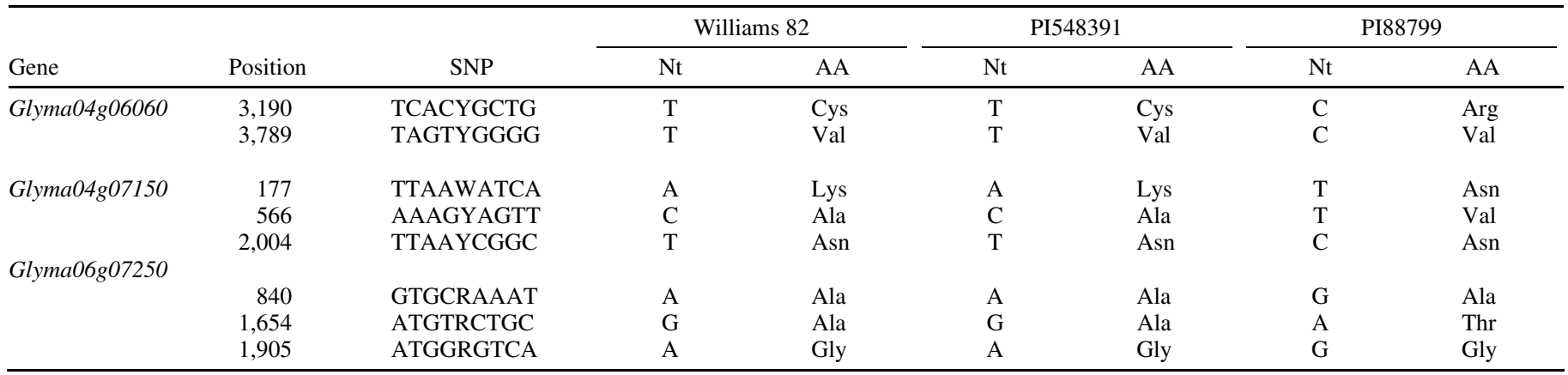


It should be noted that it is possible to separate seed transmission and seed coat mottling phenotypes. For example, PI88799 produced heavily mottled seed when infected by SMV strain G2 but showed very low seed transmission (21), which indicates that suppression of RNA silencing alone is not sufficient for embryo invasion.

HC-Pro binds 21-nt siRNA duplexes most efficiently when complexed with as-yet-unidentified host factors (42). HC-Pro interacting proteins have been identified in other systems $(4,14$, $23,34,35$ ), one of which, NbrgsCAM (2), is a plant suppressor of RNA silencing. None of those proteins had soybean homologues within the significant intervals on LGs $\mathrm{C} 1$ or C2. To identify the soybean genes required for seed transmission of SMV 413, it will be important to further narrow the intervals containing the genes-possibly through additional fine mapping in populations segregating individual loci or using association mapping of the traits in the soybean accessions from the United States Department of Agriculture Soybean Germplasm Collection.

\section{ACKNOWLEDGMENTS}

Mention of a trademark, proprietary product, or vendor does not constitute a guarantee or warranty of the product by the United States Department of Agriculture or the University of Illinois and does not imply its approval to the exclusion of other products or vendors that may also be suitable. This work was supported by the United States Department of Agriculture Cooperative State Research, Education, and Extension and Agricultural Research Services and the Illinois Soybean Association. We thank J. Davenport, M. McAllister, and D. Polychronopoulos for their assistance in genetic analysis of soybean populations; and R. Warsaw, L. Crull, and A. Waymire for their assistance in the field experiments.

\section{LITERATURE CITED}

1. Altschul, S. F., Gish, W., Miller, W., Myers, E. W., and Lipman, D. J. 1990. Basic local alignment search tool. J. Mol. Biol. 215:403-410.

2. Anandalakshmi, R., Marathe, R., Ge, X., Herr, J. M., Jr., Mau, C., Mallory, A., Pruss, G., Bowman, L., and Vance, V. B. 2000. A calmodulinrelated protein that suppresses posttranscriptional gene silencing in plants. Science 290:142-144.

3. Anandalakshmi, R., Pruss, G. J., Ge, X., Marathe, R., Mallory, A. C., Smith, T. H., and Vance, V. B. 1998. A viral suppressor of gene silencing in plants. Proc. Natl. Acad. Sci. USA 95:13079-13084.

4. Ballut, L., Drucker, M., Pugniere, M., Cambon, F., Blanc, S., Roquet, F., Candresse, T., Schmid, H. P., Nicolas, P., Gall, O. L., and Badaoui, S. 2005. HcPro, a multifunctional protein encoded by a plant RNA virus, targets the 20S proteasome and affects its enzymic activities. J. Gen. Virol. 86:2595-2603.

5. Baulcombe, D. 2004. RNA silencing in plants. Nature 431:356-363.

6. Blevins, T., Rajeswaran, R., Shivaprasad, P. V., Beknazariants, D., SiAmmour, A., Park, H. S., Vazquez, F., Robertson, D., Meins, F., Jr., Hohn, T., and Pooggin, M. M. 2006. Four plant Dicers mediate viral small RNA biogenesis and DNA virus induced silencing. Nucleic Acids Res. 34:6233-6246.

7. Bowers, G. R., and Goodman, R. M. 1991. Strain specificity of soybean mosaic virus seed transmission in soybean. Crop Sci. 31:1171-1174.

8. Brosnan, C. A., Mitter, N., Christie, M., Smith, N. A., Waterhouse, P. M., and Carroll, B. J. 2007. Nuclear gene silencing directs reception of longdistance mRNA silencing in Arabidopsis. Proc. Natl. Acad. Sci. USA 104:14741-14746.

9. Buzzell, R. I., and Tu, J. C. 1989. Inheritance of a soybean stem-tip necrosis reaction to soybean mosaic virus. J. Hered. 80:400-401.

10. Cao, M., Ye, X., Willie, K., Lin, J., Zhang, X., Redinbaugh, M. G., Simon, A. E., Morris, T. J., and Qu, F. 2010. The capsid protein of Turnip crinkle virus overcomes two separate defense barriers to facilitate viral systemic movement in Arabidopsis. J. Virol. 84:7793-7802.

11. Carroll, T. W., Gossel, P. L., and Hockett, E. A. 1979. Inheritance of resistance to seed transmission of barley stripe mosaic virus in barley. Phytopathology 69:431-433.

12. Chan, S. W., Zilberman, D., Xie, Z., Johansen, L. K., Carrington, J. C., and Jacobsen, S. E. 2004. RNA silencing genes control de novo DNA methylation. Science 303:1336.

13. Chen, P., Buss, G. R., Roane, C. W., and Tolin, S. A. 1994. Inheritance in soybean of resistant and necrotic reactions to soybean mosaic virus strains. Crop Sci. 34:414-422.

14. Cheng, Y. Q., Liu, Z. M., Xu, J., Zhou, T., Wang, M., Chen, Y. T., Li, H. F., and Fan, Z. F. 2008. HC-Pro protein of Sugar cane mosaic virus interacts specifically with maize ferredoxin-5 in vitro and in planta. J. Gen. Virol. 89:2046-2054.

15. Churchill, G. A., and Doerge, R. W. 1994. Empirical threshold values for quantitative trait mapping. Genetics 138:963-971.

16. Clough, S. J., Tuteja, J. H., Li, M., Marek, L. F., Shoemaker, R. C., and Vodkin, L. O. 2004. Features of a 103-kb gene-rich region in soybean include an inverted perfect repeat cluster of $C H S$ genes comprising the $I$ locus. Genome 47:819-831.

17. Cregan, P. B., Jarvik, T., Bush, A. L., Shoemaker, R. C., Lark, K. G., Kahler, A. L., Kaya, N., VanToai, T. T., Lohnes, D. G., Chung, J., and Specht, J. E. 1999. An integrated genetic linkage map of the soybean genome. Crop Sci. 39:1464-1490.

18. Cronin, S., Verchot, J., Haldeman-Cahill, R., Schaad, M. C., and Carrington, J. C. 1995. Long-distance movement factor: A transport function of the potyvirus helper component proteinase. Plant Cell 7:549-559.

19. Ding, S. W., and Voinnet, O. 2007. Antiviral immunity directed by small RNAs. Cell 130:413-426.

20. Domier, L. L., Franklin, K. M., Hunt, A. G., Rhoads, R. E., and Shaw, J. G. 1989. Infectious in vitro transcripts from cloned cDNA of a potyvirus, tobacco vein mottling virus. Proc. Natl. Acad. Sci. USA 86:3509-3513.

21. Domier, L. L., Steinlage, T. A., Hobbs, H. A., Wang, Y., HerreraRodriguez, G., Haudenshield, J. S., McCoppin, N. K., and Hartman, G. L. 2007. Similarities in seed and aphid transmission among Soybean mosaic virus isolates. Plant Dis. 91:546-550.

22. Dunoyer, P., Schott, G., Himber, C., Meyer, D., Takeda, A., Carrington, J. C., and Voinnet, O. 2010. Small RNA duplexes function as mobile silencing signals between plant cells. Science 328:912-916.

23. Guo, D., Spetz, C., Saarma, M., and Valkonen, J. P. 2003. Two potato proteins, including a novel RING finger protein (HIP1), interact with the potyviral multifunctional protein HCpro. Mol. Plant-Microbe Interact. $16: 405-410$.

24. Hajimorad, M. R., Eggenberger, A. L., and Hill, J. H. 2006. Strainspecific P3 of Soybean mosaic virus elicits Rsv1-mediated extreme resistance, but absence of $\mathrm{P} 3$ elicitor function alone is insufficient for virulence on Rsv1-genotype soybean. Virology 345:156-166.

25. Hajimorad, M. R., and Hill, J. H. 2001. Rsv1-mediated resistance against Soybean mosaic virus- $\mathrm{N}$ is hypersensitive response-independent at inoculation site, but has the potential to initiate a hypersensitive responselike mechanism. Mol. Plant-Microbe Interact. 14:587-598.

26. Hake, S., Smith, H. M., Holtan, H., Magnani, E., Mele, G., and Ramirez, J. 2004. The role of knox genes in plant development. Annu. Rev. Cell. Dev. Biol. 20:125-151.

27. Hayes, A. J., Ma, G. R., Buss, G. R., and Maroof, M. A. S. 2000. Molecular marker mapping of RSV4, a gene conferring resistance to all known strains of Soybean mosaic virus. Crop Sci. 40:1434-1437.

28. Hernandez-Pinzon, I., Yelina, N. E., Schwach, F., Studholme, D. J., Baulcombe, D., and Dalmay, T. 2007. SDE5, the putative homologue of a human mRNA export factor, is required for transgene silencing and accumulation of trans-acting endogenous siRNA. Plant J. 50:140-148.

29. Hill, J. H. 1999. Soybean mosaic virus. Pages 70-71 in: Compendium of Soybean Diseases. G. L. Hartman, J. B. Sinclair, and J. C. Rupe, eds. The American Phytopathological Society, St. Paul, MN

30. Himber, C., Dunoyer, P., Moissiard, G., Ritzenthaler, C., and O., V. 2003. Transitivity-dependent and -independent cell-to-cell movement of RNA silencing. EMBO J. 22:4523-4533.

31. Hobbs, H. A., Hartman, G. L., Wang, Y., Hill, C. B., Bernard, R. L., Pedersen, W. L., and Domier, L. L. 2003. Occurrence of seed coat mottling in soybean plants inoculated with Bean pod mottle virus and Soybean mosaic virus. Plant Dis. 87:1333-1336.

32. Hull, R. 2002. Matthew's Plant Virology. Academic Press.

33. Jeong, S. C., Kristipati, S., Hayes, A. J., Maughan, P. J., Noffsinger, S. L., Gunduz, I., Buss, G. R., and Maroof, M. A. 2002. Genetic and sequence analysis of markers tightly linked to the Soybean mosaic virus resistance gene, Rsv3. Crop Sci. 42:265-270

34. Jin, Y., Ma, D., Dong, J., Jin, J., Li, D., Deng, C., and Wang, T. 2007. HCPro protein of Potato virus $Y$ can interact with three Arabidopsis $20 \mathrm{~S}$ proteasome subunits in planta. J. Virol. 81:12881-12888.

35. Jin, Y., Ma, D., Dong, J., Li, D., Deng, C., Jin, J., and Wang, T. 2007. The HC-pro protein of Potato virus $Y$ interacts with NtMinD of tobacco. Mol. Plant-Microbe Interact. 20:1505-1511.

36. Joehanes, R., and Nelson, J. C. 2008. QGene 4.0, an extensible Java QTLanalysis platform. Bioinformatics 24:2788-2789.

37. Johansen, E., Edwards, M. C., and Hampton, R. O. 1994. Seed transmission of viruses - current perspectives. Annu. Rev. Phytopathol. 32:363-386.

38. Johansen, I. E., Dougherty, W. G., Keller, K. E., Wang, D., and Hampton, R. O. 1996. Multiple viral determinants affect seed transmission of pea 
seedborne mosaic virus in Pisum sativum. J. Gen. Virol. 77:3149-3154.

39. Kasai, A., Ohnishi, S., Yamazaki, H., Funatsuki, H., Kurauchi, T., Matsumoto, T., Yumoto, S., and Senda, M. 2009. Molecular mechanism of seed coat discoloration induced by low temperature in yellow soybean. Plant Cell Physiol. 50:1090-1098.

40. Khan, N. A., Githiri, S. M., Benitez, E. R., Abe, J., Kawasaki, S., Hayashi, T., and Takahashi, R. 2008. QTL analysis of cleistogamy in soybean. Theor. Appl. Genet. 117:479-487.

41. Kiihl, R. A. A., and Hartwig, E. E. 1979. Inheritance of reaction to soybean mosaic virus in soybeans. Crop Sci. 19:372-375.

42. Lakatos, L., Csorba, T., Pantaleo, V., Chapman, E. J., Carrington, J. C., Liu, Y. P., Dolja, V. V., Calvino, L. F., Lopez-Moya, J. J., and Burgyan, J. 2006. Small RNA binding is a common strategy to suppress RNA silencing by several viral suppressors. EMBO J. 25:2768-2780.

43. Lander, E. S., Green, P., Abrahamson, J., Barlow, A., Daly, M. J., Lincoln, S. E., and Newburg, L. 1987. MAPMAKER: an interactive computer package for constructing primary genetic linkage maps of experimental and natural populations. Genomics 1:174-181.

44. Li, H., Ye, G., and Wang, J. 2007. A modified algorithm for the improvement of composite interval mapping. Genetics 175:361-374.

45. Li, W., Zheng, D. H., Van, K., and Lee, S. H. 2008. QTL mapping for major agronomic traits across two years in soybean (Glycine max L. Merr.). J. Crop Sci. Biotechnol. 11:171-190.

46. Lin, N. S., Hsu, Y. H., and Hsu, H. T. 1990. Immunological detection of plant viruses and a mycoplasmalike organism by direct tissue blotting on nitrocellulose membranes. Phytopathology 80:824-828.

47. Liu, B., Fujita, T., Yan, Z. H., Sakamoto, S., Xu, D., and Abe, J. 2007. QTL mapping of domestication-related traits in soybean (Glycine max). Ann. Bot. 100:1027-1038.

48. Ma, G., Chen, P., Buss, G. R., and Tolin, S. A. 1995. Genetic characteristics of two genes for resistance to soybean mosaic virus in p1486355 soybean. Theor. Appl. Genet. 91:907-914.

49. Mallory, A. C., Ely, L., Smith, T. H., Marathe, R., Anandalakshmi, R., Fagard, M., Vaucheret, H., Pruss, G., Bowman, L., and Vance, V. B. 2001. HC-Pro suppression of transgene silencing eliminates the small RNAs but not transgene methylation or the mobile signal. Plant Cell 13:571-583.

50. Maroof, M. A. S., Jeong, S. C., Gunduz, I., Tucker, D. M., Buss, G. R., and Tolin, S. A. 2008. Pyramiding of soybean mosaic virus resistance genes by marker-assisted selection. Crop Sci. 48:517-526.

51. Martins, W. S., Soares Lucas, D. C., de Souza Neves, K. F., and Bertioli, D. J. 2009. WebSat-a web software for microsatellite marker development. Bioinformation 3:282-283.

52. Moissiard, G., and Voinnet, O. 2006. RNA silencing of host transcripts by cauliflower mosaic virus requires coordinated action of the four Arabidopsis Dicer-like proteins. Proc. Natl. Acad. Sci. USA 103:19593-19598.

53. Muangsan, N., Beclin, C., Vaucheret, H., and Robertson, D. 2004. Geminivirus VIGS of endogenous genes requires SGS2/SDE1 and SGS3 and defines a new branch in the genetic pathway for silencing in plants. Plant J. 38:1004-1014.

54. Pathipanawat, W., Jones, R. A. C., and Sivasithamparam, K. 1997. Factors influencing transmission of alfalfa mosaic virus through seed of annual medics (Medicago spp.) and the genetic control of seed transmission rate. Aust. J. Agric. Res. 48:989-997.

55. Peragine, A., Yoshikawa, M., Wu, G., Albrecht, H. L., and Poethig, R. S. 2004. SGS3 and $S G S 2 / S D E 1 / R D R 6$ are required for juvenile development and the production of trans-acting siRNAs in Arabidopsis. Genes Dev. 18:2368-2379.

56. Pfeil, B. E., Schlueter, J. A., Shoemaker, R. C., and Doyle, J. J. 2005. Placing paleopolyploidy in relation to taxon divergence: A phylogenetic analysis in legumes using 39 gene families. Syst. Biol. 54:441-454.

57. Qu, F., Ye, X., Hou, G., Sato, S., Clemente, T. E., and Morris, T. J. 2005. RDR6 has a broad-spectrum but temperature-dependent antiviral defense role in Nicotiana benthamiana. J. Virol. 79:15209-15217.

58. Qu, F., Ye, X., and Morris, T. J. 2008. Arabidopsis DRB4, AGO1, AGO7, and RDR6 participate in a DCL4-initiated antiviral RNA silencing pathway negatively regulated by $D C L 1$. Proc. Natl. Acad. Sci. USA 105:14732-14377.

59. Roberts, I. M., Wang, D., Thomas, C. L., and Maule, A. J. 2003. Pea seedborne mosaic virus seed transmission exploits novel symplastic pathways to infect the pea embryo and is, in part, dependent upon chance. Protoplasma 222:31-43

60. Schmutz, J., Cannon, S. B., Schlueter, J., Ma, J., Mitros, T., Nelson, W., Hyten, D. L., Song, Q., Thelen, J. J., Cheng, J., Xu, D., Hellsten, U., May, G. D., Yu, Y., Sakurai, T., Umezawa, T., Bhattacharyya, M. K., Sandhu, D., Valliyodan, B., Lindquist, E., Peto, M., Grant, D., Shu, S., Goodstein, D., Barry, K., Futrell-Griggs, M., Abernathy, B., Du, J., Tian, Z., Zhu, L., Gill, N., Joshi, T., Libault, M., Sethuraman, A., Zhang, X. C., Shinozaki, K., Nguyen, H. T., Wing, R. A., Cregan, P., Specht, J., Grimwood, J., Rokhsar, D., Stacey, G., Shoemaker, R. C., and Jackson, S. A. 2010. Genome sequence of the palaeopolyploid soybean. Nature 463:178-183.

61. Senda, M., Masuta, C., Ohnishi, S., Goto, K., Kasai, A., Sano, T., Hong, J. S., and MacFarlane, S. 2004. Patterning of virus-infected Glycine max seed coat is associated with suppression of endogenous silencing of chalcone synthase genes. Plant Cell 16:807-818.

62. Shi, A. N., Chen, P. Y., Li, D. X., Zheng, C. M., Zhang, B., and Hou, A. F. 2009. Pyramiding multiple genes for resistance to soybean mosaic virus in soybean using molecular markers. Mol. Breed. 23:113-124.

63. Stonebloom, S., Burch-Smith, T., Kim, I., Meinke, D., Mindrinos, M., and Zambryski, P. 2009. Loss of the plant DEAD-box protein ISE1 leads to defective mitochondria and increased cell-to-cell transport via plasmodesmata. Proc. Natl. Acad. Sci. USA 106:17229-17234.

64. Tamura, K., Dudley, J., Nei, M., and Kumar, S. 2007. MEGA4: Molecular Evolutionary Genetics Analysis (MEGA) software version 4.0. Mol. Biol. Evol. 24:1596-1599.

65. Thompson, J. D., Gibson, T. J., Plewniak, F., Jeanmougin, F., and Higgins, D. G. 1997. The CLUSTALX windows interface: Flexible strategies for multiple sequence alignment aided by quality analysis tools. Nucleic Acids Res. 25:4876-4882.

66. Todd, J. J., and Vodkin, L. O. 1993. Pigmented soybean (Glycine max) seed coats accumulate proanthocyanidins during development. Plant Physiol. 102:663-670.

67. Todd, J. J., and Vodkin, L. O. 1996. Duplications that suppress and deletions that restore expression from a chalcone synthase multigene family. Plant Cell 8:687-699.

68. Tuteja, J. H., Zabala, G., Varala, K., Hudson, M., and Vodkin, L. O. 2009. Endogenous, tissue-specific short interfering RNAs silence the chalcone synthase gene family in Glycine max seed coats. Plant Cell 21:3063-3077.

69. Wang, D., Shi, J., Carlson, S. R., Cregan, P. B., Ward, R. W., and Diers, B. W. 2003. A low-cost, high-throughput polyacrylamide gel electrophoresis system for genotyping with microsatellite DNA markers. Crop Sci. 43:1828-1832

70. Wang, D. W., and Maule, A. J. 1994. A model for seed transmission of a plant virus-genetic and structural analyses of pea embryo invasion by pea seed-borne mosaic virus. Plant Cell 6:777-787.

71. Wang, X. B., Wu, Q., Ito, T., Cillo, F., Li, W. X., Chen, X., Yu, J. L., and Ding, S. W. 2010. RNAi-mediated viral immunity requires amplification of virus-derived siRNAs in Arabidopsis thaliana. Proc. Natl. Acad. Sci. USA 107:484-489.

72. Yang, J., Hu, C. C., Ye, X. Z., Zhu, Z., and Zhu, J. 2009. QTL Network 2.1. Institute of Bioinformatics, Zhejiang University, Hangzhou, China http://ibi.zju.edu.cn/software/qtlnetwork/

73. Yoshii, A., Shimizu, T., Yoshida, A., Hamada, K., Sakurai, K., Yamaji, Y., Suzuki, M., Namba, S., and Hibi, T. 2008. NTH201, a novel class II KNOTTED1-like protein, facilitates the cell-to-cell movement of Tobacco mosaic virus in tobacco. Mol. Plant-Microbe Interact. 21:586-596.

74. Yu, Y. G., Maroof, M. A. S., Buss, G. R., Maughan, P. J., and Tolin, S. A. 1994. RFLP and microsatellite mapping of a gene for soybean mosaic virus resistance. Phytopathology 84:60-64. 